\title{
Assessing Forest-based Rural Communities' Adaptive Capacity and Coping Strategies for Climate Variability and Change: The case of Vhembe District in South Africa
}

\author{
Chidiebere Ofoegbu ${ }^{1 *}$, P. W. Chirwa ${ }^{1}$, J. Francis $^{2}$ and F. D. Babalola ${ }^{1,3}$ \\ ${ }^{1}$ Forest Science Postgraduate Programme, Department of Integrated Plant and Soil Sciences, \\ University of Pretoria, 5-15 Plant Sciences Complex, Pretoria, South Africa \\ ${ }^{2}$ Institutes for Rural Development, University of Venda, Thohoyandou 0950, South Africa \\ ${ }^{3}$ Department of Forest Resources Management,University of Ilorin, Ilorin, Nigeria \\ *Tel: +2710909153; Email: ofoegbu.c@gmail.com
}

\begin{abstract}
In this study, various coping strategies used by forest-based rural communities in Vhembe District of South Africa in response to climate variability and change challenges were investigated. The effect of community socio-demographic characteristics on the adaptive capacity and choice/effectiveness of coping strategies was examined. Household level data were collected from 366 respondents selected from 21 rural communities using the proportionate random sampling procedure. The Pearson Chisquare test was used to analyse the coping strategies. The effects of household and community sociodemographic characteristics on choice and effectiveness of coping strategies were determined using the binary logit model. It was observed that the respondents used diverse coping strategies, depending on the nature of climate variability and extreme weather events they were confronted with. Rainwater harvesting was the most popular strategy that the respondents in Makhado (90\%), Mutale (96.3\%), and Thulamela (50\%) used to cope with erratic rainfall. Tree planting around houses and on farmland were the most popular strategies (90-100\%) to counter the effects of extreme temperature. Furthermore, household and community demographic characteristics in particular education and skills levels, and forest products, institutional services and infrastructure available in the communities such as markets, and water supply facilities significantly $(\mathrm{p}<0.05)$ influenced the choice of households' coping strategies. Therefore, it can be hypothesized that efforts that enhance the household's capacity and community infrastructural development might be viable and sustainable ways of improving rural communities' resilience to climate change and variability challenges.
\end{abstract}

Keywords: Climate variability and change, community resilience, coping strategy, livelihood, adaptation, adaptive capacity

\section{INTRODUCTION}

Forest-based rural communities in Africa are increasingly becoming the focal point in climate change discourse, mainly due to their vulnerability to climate variability and change challenges (Coulibaly et al., 2015). This is due to their high level of dependence on forests and natural resources for livelihood (Robledo et al., 2012; Coulibaly et al., 2015). Prolonged impact of climate change might result in increased poverty and unsustainable rural development (Boon and Ahenkan, 2012; Hammil et al., 2013). Thus, there is a growing need to address vulnerabilities of rural people to climate change (Helgeson et al., 2013).

The 2015 Paris agreement, which is aimed at advancing and fostering international cooperation towards implementation of programs that might accelerate transition towards a low-carbon economy and climate-resilient society (Sebastian et al. 2015), added impetus to the many national and multilateral commitments, actions and initiatives that seek to address climate change through capacity enhancement (Viljoen, 2013). For many developing countries, particularly in Africa, this represents a unique opportunity for international cooperation and attracting technical and financial support towards establishment of an improved modality for reducing the vulnerability of communities facing climate 
impacts. This will facilitate meaningful incorporation of rural communities in climate change adaptation and mitigation initiatives.

Residents of rural areas rely on their own coping mechanisms that help them to cushion the effect of climate variability and extreme weather events (Perlis, 2009; Coulibaly et al., 2015). Indigenous knowledge and utilization of natural resources such as non-timber forest products (NTFPs) as a safety net have been useful coping strategies (Valdivia et al., 2005; Shackleton et al. 2008; Angela et al., 2010; Locatelli et al., 2010; Pramova et al., 2012; Wilk et al., 2013). However, despite past success in dealing with climate variability and extreme weather events, there are concerns that the coping strategies in use could be less effective in handling the accelerated pace of climate change-induced occurrence of extreme weather events (Adger et al., 2007; Wilk et al., 2013). This highlights the need for determining whether the current coping strategies that rural households use can be transformed into sustainable adaptive strategies to ensure livelihood security under climate change challenges (Wall and Marzall, 2006; Thomas et al., 2007).

Coping strategies are short-term actions used to ward off immediate risk and are often not relevant in reducing vulnerability in the long-term (Turner et al., 2003I; The International Centre for Integrated Mountain Development: ICIMOD, 2007). Nevertheless, they provide useful insights on how to develop more practical, sustainable, and localised adaptation strategies (Twomlow et al., 2008; Fisher et al., 2010). Moreover, coping strategies are often location-specific. Thus, it is necessary to assess coping strategies specific to forest-based communities in order to develop appropriate locationspecific policies and interventions (Williams and Kalamandeen, 2013; Nkomwa et al., 2014). In support of the Wilk et al. (2013) argument, interventions designed to enable adaptation are likely to be successful if they are localised. This originates from the fact that adaptation to climate change is inevitably and unavoidably local. Therefore, this study was based on the notion that incorporating current local coping strategies into climate change policies and interventions can lead to cost effective, participatory, locally relevant and sustainable interventions (Twomlow et al., 2008; Nkomwa, et al., 2014).

Past experience of manifestations of extreme weather events in rural communities suggest that: (a) not all households have the capacity to adapt to the challenges of climate change (CARE, 2011), and (b) not all households' current coping strategies are effective in combating the risks associated with climate change (Angela et al., 2010). In addition, several studies (Moghal, 2011; Goldman and Riosmen, 2013; Byrne, 2014; CARE, 2014; Egyir et al., 2015) have revealed that households, even within the same community adopt different coping strategies. Adaptive capacity is a consequence of the extent of vulnerability and/or resilience to climate change (Helgeson et al., 2013; Byrne, 2014). Joerin et al. (2012) found similar results in Chennai, India. In the latter study, despite the households' past experience of flood-related disasters, their resilience remained very low due to their limited adaptive capacity. This implies that without appropriate adaptive capacity, the resilience of households to climate disaster is limited to the cycle of absorbing, managing and bouncing back (Joerin et al., 2012; Robledo et al., 2012).

The extent to which households and communities adapt to the impact of climate change significantly affects sustainable development (Byrne, 2014). However, it does not mean that high adaptive capacity translates to improved resilience to climate change (Amisah et al., 2009). Sometimes, there are underlying socioeconomic conditions that either facilitate or hinder adaptive capacity (Hughey and Becken, 2014). Several authors (Adeniji-Oloukoi et al., 2013; Williams and Kalamandeen, 2013; Byrne, 2014; CARE, 2014) have reported that adaptive capacity at either household or community level depends on demographic factors such as access to information, social, human, institutional, natural and economic resources, and technologies. Thus, there is need for studies that identify attributes or socio-demographic factors that aid the climate change adaptation capacity of households (Panda et al., 2013).

Scholars such as Alberini et al. (2006) and Elrick-Barr et al. (2015) have pointed out the difficulty of identifying and carrying out empirical analyses of the relative importance of socio-demographic 
factors in households' adaptive capacities. Moreover, most studies on capacity to adapt to climate change (Nzuma et al., 2010; Arnall, 2012; Lemos, 2013; Tembo, 2013) have focused mainly on national level assessments that utilize indicators and indices (Byrne, 2014). Yet national scale indicators of adaptive capacity are too broad for practical application at local community level (Tembo, 2013). Nevertheless, adaptive capacity assessment significantly contributes to climate change management at household or local community level (Elrick-Barr et al., 2014).

Taking into account the numerous issues highlighted above, this study was carried out to clarify the complex human-environment interaction in forest-based rural communities of Vhembe district in Limpopo Province of South Africa. The socioeconomic conditions that affected coping strategies that the communities used and adaptive capacity of households to climate change were investigated. Specifically, the study was designed to identify the coping strategies of the households to climate variability and the roles of forests in this regard. Additionally, it sought to establish the adequacy and effectiveness of the coping strategies. The following research questions anchored the study:

(i) How does a household respond to perceived climate variability and change?

(ii) Do forests play any role in the coping strategies that households choose and how effective are these?

(iii) Are there factors constraining or enhancing households' adaptive capacities?

(iv) Which attributes of adaptive capacity are crucial for the household coping strategies and should they be enhanced?

(v) Do the attributes of adaptive capacity influence households' choices of coping strategies?

\section{METHODOLOGY}

\subsection{Study Area}

As already revealed above, the study was conducted in Vhembe District Municipality, which is located in Limpopo Province of the Republic of South Africa $\left(22^{\circ} 56 \mathrm{~S}, 30^{\circ} 28 \mathrm{E}\right.$, Figure 1). Makhado, Musina, Mutale and Thulamela municipalities constitute the district. In Vhembe district, there are approximately 1.2 million with females accounting for $54.4 \%$. Most of the people $(48.7 \%)$ are found in Thulamela local municipality. The rest of the population is distributed as follows: Makhado (41.4\%), Mutale (6.6\%), and Musina (3.3\%) (Statistics South Africa: SSA, 2011). Tshivenda-speaking people make up $69 \%$ of the population, followed by the Xitsonga speakers $(27 \%)$. In order to cover the various representations in the district in relation to the study objectives, vegetation type and dominant livelihood strategy were considered in the selection of Makhado, Mutale and Thulamela municipalities as the focal area of study.

The landscape of selected communities in Makhado, Mutale and Thulamela is made up of Savannah, semi-arid zones and woodland vegetation, respectively (Rosmarin 2013). Rainfall received in Makhado occurs mainly in the summer months, extending from November to March (Quinn et al.., 2011; Vhembe Biosphere Reserve: VBR, 2012; Turpie and Visser, 2013). Mutale municipality receives about $681 \mathrm{~mm}$ of rainfall per year, with most of it occurring during mid-summer (Marrewijk, 2011; VBR, 2012). In Thulamela municipality, most of the rainfall falls between October and January (VBR, 2012). Projections in the South African National Climate Change Response Strategy reveal that in Vhembe district, temperature is expected to increase in the range $1{ }^{0} \mathrm{C}$ to $3^{0} \mathrm{C}$ by the mid- $21 \mathrm{st}$ century (Department of Environmental Affairs and Tourism: DEAT, 2004). Furthermore, it is projected that rainfall amounts will be reduced by 5\% to 10\% (DEAT, 2004). These changes in climate are likely to severely impact on rural livelihood strategies such as farming, livestock keeping and use of forest products, thereby increasing the vulnerability of the affected communities (Paumgarten and Shackleton, 2011; Turpie and Visser, 2013). Apart from this, in Vhembe District unemployment rates are high and most rural households depend on social grants (VBR, 2012). The 
interconnectedness of social, ecological, and human systems makes these communities acutely sensitive to the impacts of climate change (Intergovernmental Panel on Climate Change: IPCC, 2007).

\subsection{Sampling framework}

In each of the selected municipalities, 7 rural communities were selected, implying that 21 rural communities constituted the overall sample for this study. The stratified proportionate random sampling procedure was used to select the 366 households that were interviewed. Enumeration area (EA) maps of the selected communities, which contained the total number of households and their location, were used to divide the communities into three strata. Thereafter, they were proportionately and randomly selected households from each stratum. The coordinates of the selected households were entered into Germain etrex30 GPS and used to track the location of each house during the questionnaire administration period. Each household was selected for questionnaire administration using a non-probability purposive sampling technique. Respondents in a household were supposed to (a) be more than 20 years old and (b) have lived in their community for more than five years.

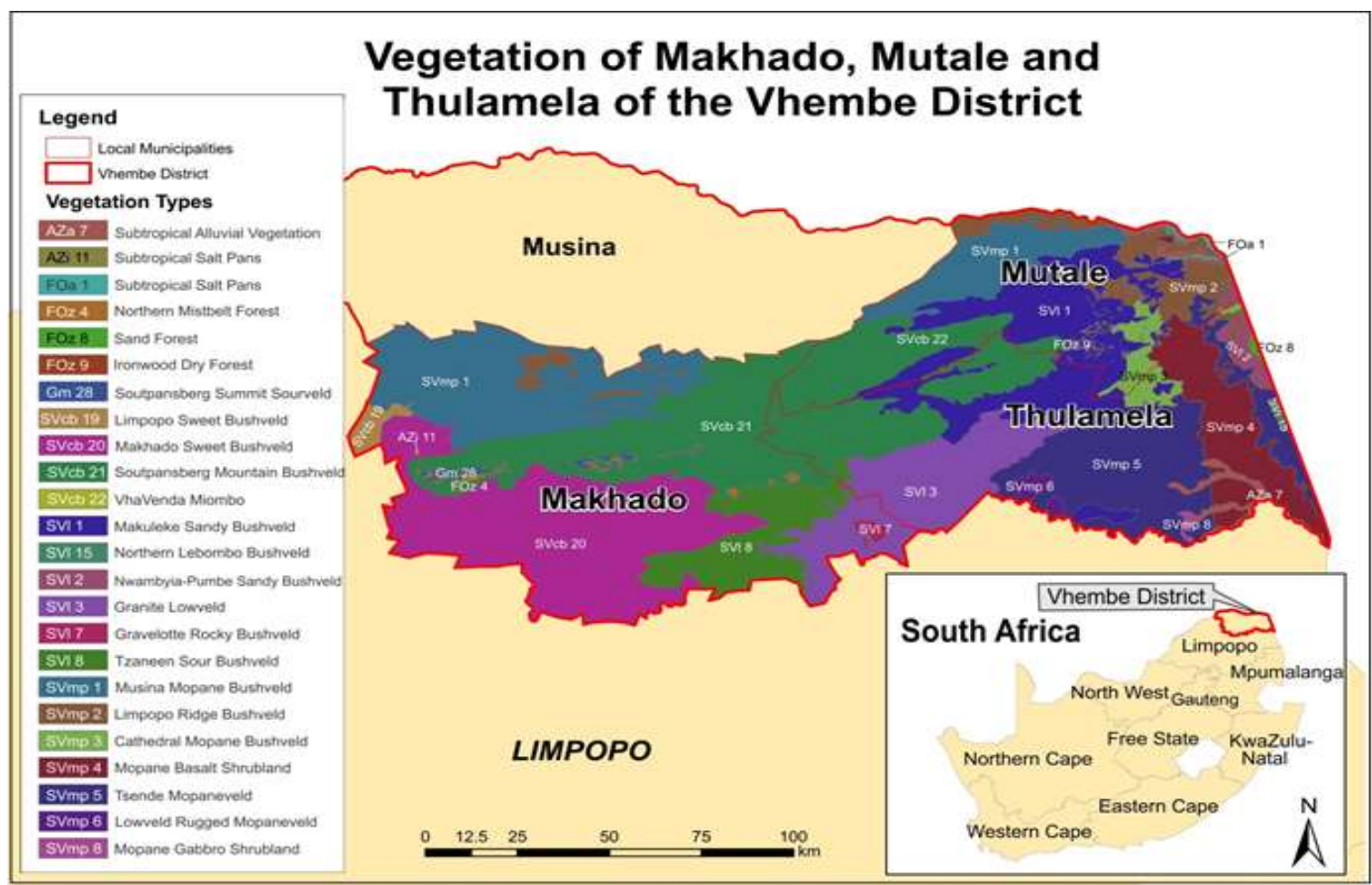

Figure 1: Map of Vhembe District showing the study communities (Source: SSA, 2011)

\subsubsection{Data collection}

Both primary and secondary data were collected. Primary data were collected through household surveys, discussions with leaders of villages and field observations. The household questionnaire was selected because it provided a quantitative way of measuring the coping responses and adaptive capacities of households in relation to climate change. Evidence from the literature suggests that this method has merit in providing baseline household data on the residents' ability to respond to and cope with climate change (McNamara, 2011). Secondary information was also used in the study and it entailed carrying out a critical review of relevant literature on the government's climate change programme as well as forest policy, legislation and relevant strategy documents.

\section{Analysis of Coping Strategies}

The coping strategies of households were analysed by asking questions on how the residents responded to climate variability and extreme weather events such as drought, erratic rainfall, extreme temperature, flooding and hailstones. The questions on effectiveness and sustainability of the coping 
strategies were also asked. In this study, the average daily temperatures of at least $31.6^{\circ} \mathrm{C}$ were regarded as extreme. The information from literature, discussion with village heads, and reconnaissance survey were used to compile a list of coping strategies used. The respondents were then asked to indicate, among the pre-determined coping strategies listed in the questionnaire, those that they had used to counter the adverse effects of climate variability and extreme weather events. They were also asked whether they perceived any difficulties in coping with climate change. Empirical analyses were also used to examine the role of forest products in the coping strategies of the households.

\section{Analysis of Adaptive Capacity}

In this study, adaptive capacity refers to the potential of the people to adapt, rather than the actual actions taken in response to adverse conditions emanating from climate change. Socio-demographic characteristics such as access to services and infrastructure, and socioeconomic conditions affect the adaptive capacity of the households. In order to understand how adaptive capacity varied across rural communities, a framework (see Figure 2) was developed taking into account the guidelines of the Sustainable Livelihoods Approach (SLA). Questions included assessing the socioeconomic factors enhancing or hindering the adaptive capacity of the households (Mendis et al., 2003; Valdivia et al., 2005; Marshall et al., 2010; Adeniji-Oloukoi et al., 2013).

The socio-demographic factors influencing household adaptive capacity that were assessed in the study area included: (i) access to information; (ii) participation or support from community-based organisations within the community; (iii) acquired knowledge and skills; and (iv) access to infrastructure.

Access to Information explains availability of knowledge regarding coping strategies and provides a basis from which households can anticipate or react in order to minimize the impact of climate variability and change.

Participation or Support from Community-based Organisations within the Community: This describes the relationships of trust and exchange among community members. It is reflected in the community's ability to act as a collective. Thus, participation of a household in community support organisations was assessed. The attitude and perspective of the people with respect to their responsibility and action towards climate change adaptation was also investigated by asking respondents questions relating to who should be responsible for taking action against climate change. Questions were based on a Likert scale that ranged from 'strongly disagree' (equal to 1) to 'strongly agree' (equal to 5).

Acquired Knowledge and Skill: Knowledge and skills influence the adaptive capacity of households. They also enable the households to anticipate changes and appropriately modify their livelihood opportunities. Levels of education and skills of members of households were assessed together with their impact on the coping responses and adaptive capacity. Available literature was used to draw up a list of skills relevant for sustainable rural livelihoods, particularly focusing on forest-based livelihoods. Respondents were then asked to indicate the skills they possessed.

Access to Infrastructure: The role of institutions vis-à-vis access to infrastructure and facilities in determining adaptive capacity is a widely accepted notion (Adger et al., 2007). Therefore, households' satisfaction with vital services such as water facility, healthcare facility, and markets in their communities and their impact on coping responses and adaptive capacity were assessed. 


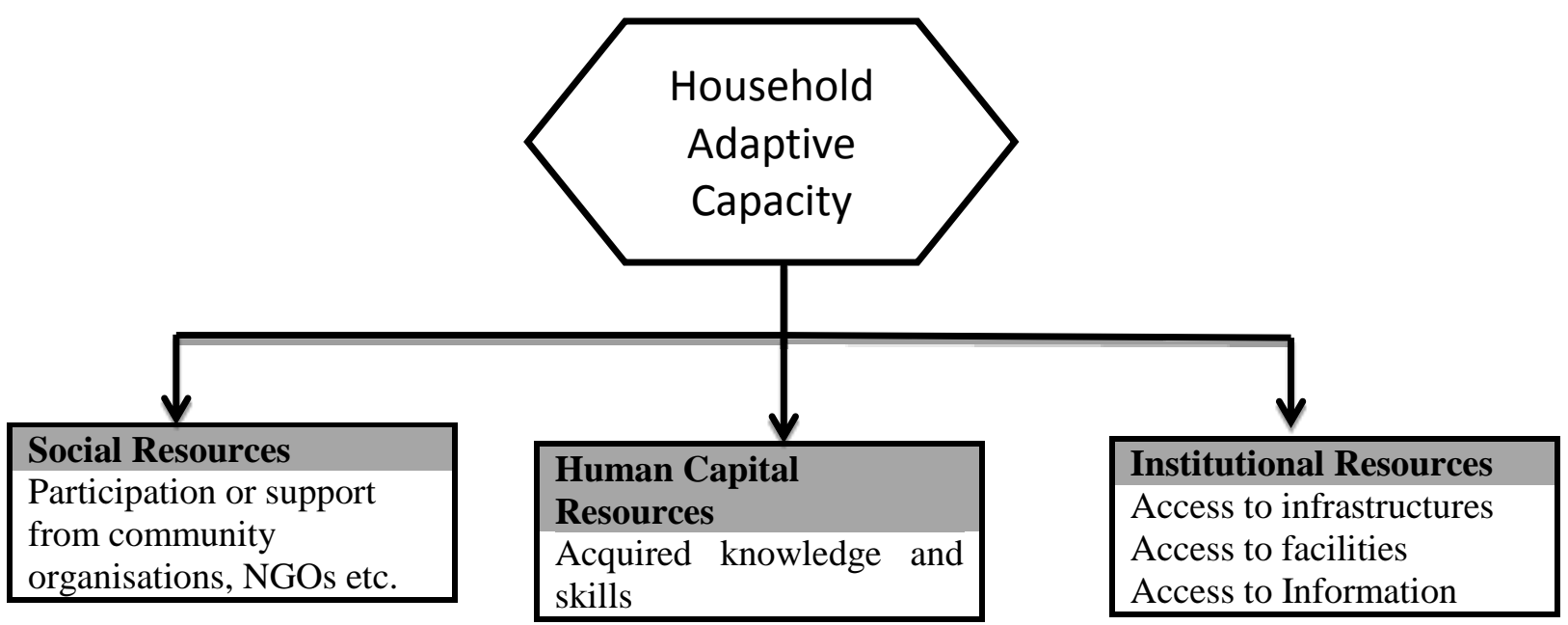

Figure 2: Household adaptive capacity analysis framework

\subsubsection{Data analysis}

Data collected using the questionnaire survey were subjected to weighting adjustment in order to correct for possible problems of either over- or under-representation of variables (Bethlehem, 2015). The sample was weighed against the actual population in order to arrive at the weighted sample. The weighted data were then analysed using the Statistical Package for the Social Sciences (SPSS) version 20 (Levesque 2007).

Discrete variables were summarised using the frequency of each code within the questionnaire. Summary statistics were computed for all numeric variables. Categorical data regarding the opinion of respondents were analysed taking individual responses into consideration. Descriptive statistics and Chi-square test were used to analyse the range of households' coping responses, current role of forest products in household coping strategies in response to climate variability and change, and influence of households and communities demographic characteristics on choice of coping strategies. Bonferoni's test was used to analyse differences across municipalities following the approach of Berg (2014). The Chi-square test was also used to determine whether there was any association between support from the social group and expressed difficulties in coping with climate variability and change. The Pearson Chi-square was used where the expected cell frequency was $\geq 5$. The Maximum-Likelihood (M-L) Chi-square was used when the expected cell frequencies were lower than five (Turyahabwe et al., 2006).

Binary logistic regression was used to analyse the influence of social resources, human capital and institutional resources on household choice of coping strategies and challenges encountered. The binary logistic regression technique was used because predictor variables in the data collected were categorical. Odds ratios were used to measure the magnitude of strength of association or nonindependence between two binary data values. If $\mathrm{p} \leq 0.05$ (less than or equal to 0.05 ), was observed, it was concluded that there existed a statistically significant difference in what was being tested (Clewer and Scarisbrick, 2001).

Satisfaction with social and institutional resources was framed as a binary-choice model, which assumed that respondents were either satisfied or not satisfied with social resources and/or institutional resources in their communities. Human capital vis-à-vis educational level was framed as binary (educated or not educated). Satisfaction with social resources, institutional resources, and human capital were depended on identifiable characteristics. Thus, let $\mathrm{T}_{\mathrm{i}}$ represent a dichotomous variable that equals 1 if respondents are satisfied with social, human and institutional resources in their communities, and 0 if they are not satisfied. 
The probability of being satisfied with social and institutional resources, and human capital were in each case, $\operatorname{Pr}\left(T_{i}=1\right)$, which is the cumulative density function $F$ evaluated at $X_{i} \beta$, where $X_{i}$ is a vector of explanatory variables and $\beta$ is a vector of unknown parameters (Maddala, 1983). The cumulative density function was modelled using the following logistic probability function:

$$
\operatorname{Pr}(\mathrm{Ti}=1)=\frac{\exp (X i \beta)}{1+\exp (X i \beta)}
$$

Dependent variables were distinctly satisfaction with social and institutional resources, and human capital, which take the value of 1 if the respondents were satisfied and 0 if not. The social resources, human capital and institutional resources were separately analysed. In the case of social resources, satisfaction with the social support group in the community was used. For institutional resources, satisfaction with water supply was considered. Level of education of the respondent constituted human capital. The explanatory variables that were included in the model are presented in Table 1. The Chi-square test at $\mathrm{p}=0.05$ significance level was used to assess the goodness of fit of the models.

Table 1: Explanatory variables used in the binary logistic model

\begin{tabular}{llll}
\hline Explanatory variables & Possible response & \\
\cline { 2 - 3 } & & $\mathbf{1}$ & $\mathbf{0}$ \\
\hline a) & Employment status & employed & Not employed \\
b) & Farming skills & yes & no \\
c) & Livestock keeping skills & yes & no \\
d) & Carpentry skills & yes & no \\
e) & Education level & educated & Not educated \\
f) & Less than or equal to 38 years of residency in the community & yes & no \\
g) & $39-52$ years of residency in the community & yes & no \\
h) & $53-65$ years of residency in the community & yes & no \\
i) & 66 years and above length of residency in the community & yes & no \\
j) & Respondents age category: $\leq 38$ & yes & no \\
k) & Respondents age category: $39-52$ years & Yes & No \\
1) & Respondents age category: $53-65$ years & Yes & No \\
m) & Respondents age category: 66 years and above & yes & No \\
\hline
\end{tabular}

\section{RESULTS AND DISCUSSION}

\subsection{Coping strategies applied by local communities}

In this study, it was observed that the residents of Makhado, Musina and Thulamela municipalities used various coping strategies to cushion the effect of climate variability and extreme weather events on their lives and livelihood. The strategies varied depending on the type of extreme weather event they were confronted with. Some of the strategies were not appropriate for long-term adaptation. For instance, a strategy such as growing crops around streams in response to erratic rainfall events may not be suitable for long-term adaptation. This is due to the fact that if erratic rainfall persisted for many seasons, streams might dry up. Likewise, a strategy such as migration to urban areas in search of employment opportunities used to cope with a drought event is an inappropriate long-term adaptation strategy. Rural-urban migration precipitates severe service delivery problems in the informal settlement areas in the urban areas. In order to draw better meaning from the results of the current study, the coping strategies were categorized as follows: 


\subsubsection{Coping strategies for dealing with erratic rainfall events}

In Table 2, it is shown that the households in the surveyed communities relied on several livelihood strategies that helped them cope with the negative effects of erratic rainfall. It is shown that taking up off-farm activities was a strategy that was mainly confined to Mutale municipality. This practice mostly practiced in response to erratic rainfall. It entailed engaging in off-farm activities either within or outside the municipal area. Although this is effective in the short-term, limited opportunities for off-farm employment in the district make it unsustainable. This is particularly significant considering that Vhembe district is largely rural with high unemployment rate reaching $40 \%$ in some places (SSA, 2011). Because of this challenge, the continuous practice of 'taking off-farm activity' may lead to considerable rural-urban migration challenges and hinder local development. Thus, it is necessary to promote socioeconomic development of the communities as a way of reducing household dependence on off-farm activity to cope with erratic rainfall.

Table 2: Coping strategies for erratic rainfall among forest-based rural households' in Vhembe District of South Africa

\begin{tabular}{|c|c|c|c|c|}
\hline \multirow[t]{2}{*}{ Coping strategies } & \multirow[t]{2}{*}{ Responses } & \multicolumn{3}{|c|}{ Proportion of respondents $(\%)$} \\
\hline & & $\begin{array}{l}\text { Makhado (n } \\
=156)\end{array}$ & $\begin{array}{l}\text { Mutale (n } \\
=110)\end{array}$ & $\begin{array}{l}\text { Thulamela (n } \\
=100)\end{array}$ \\
\hline \multirow{3}{*}{$\begin{array}{l}\text { Shifts in planting period to coincide with the start } \\
\text { of rainy season }\end{array}$} & Yes & $51.6^{\mathrm{a}}$ & $78.0^{\mathrm{b}}$ & $38.0^{\mathrm{a}}$ \\
\hline & No & $48.4^{\mathrm{a}}$ & $22.0^{\mathrm{b}}$ & $62.0^{\mathrm{a}}$ \\
\hline & Binomial test & $0.4679^{\mathrm{ns}}$ & $0.0000 *$ & $0.0105 *$ \\
\hline \multirow[t]{3}{*}{ Taken off-farm activities } & Yes & $40.1^{\mathrm{a}}$ & $65.1^{b}$ & $43.0^{\mathrm{a}}$ \\
\hline & No & $59.9^{\mathrm{a}}$ & $34.9^{\mathrm{b}}$ & $57.0^{\mathrm{a}}$ \\
\hline & Binomial test & $0.0014 *$ & $0.0016 *$ & $0.0284 *$ \\
\hline \multirow{3}{*}{$\begin{array}{l}\text { Depended on use and marketing of none timber } \\
\text { forest products }\end{array}$} & Yes & $41.0^{\mathrm{a}}$ & $45.9^{\mathrm{a}}$ & $13.0^{\mathrm{b}}$ \\
\hline & No & $59.0^{\mathrm{a}}$ & $54.1^{\mathrm{a}}$ & $87.0^{\mathrm{b}}$ \\
\hline & Binomial test & $0.0853^{\mathrm{ns}}$ & $0.2543^{\mathrm{ns}}$ & $0.0000 *$ \\
\hline \multirow[t]{3}{*}{ Cropping around streams } & Yes & $50.6^{\mathrm{a}}$ & $4.6^{\mathrm{b}}$ & $22.0^{c}$ \\
\hline & No & $49.4^{\mathrm{a}}$ & $95.4^{\mathrm{b}}$ & $78.0^{\mathrm{c}}$ \\
\hline & Binomial test & $0.2342^{\mathrm{ns}}$ & $0.0000 *$ & $0.0000 *$ \\
\hline \multirow[t]{3}{*}{ Use of dug out wells for irrigation } & Yes & $82.2^{\mathrm{a}}$ & $96.4^{b}$ & $31.0^{\mathrm{c}}$ \\
\hline & No & $17.8^{\mathrm{a}}$ & $3.6^{\mathrm{b}}$ & $69.0^{\mathrm{c}}$ \\
\hline & Binomial test & $0.0000^{*}$ & $0.0000 *$ & $0.0000 *$ \\
\hline \multirow[t]{3}{*}{ Planting drought resistant crop e.g. water melon } & Yes & $89.2^{\mathrm{a}}$ & $92.7^{\mathrm{a}}$ & $37.0^{\mathrm{b}}$ \\
\hline & No & $10.8^{\mathrm{a}}$ & $7.3^{\mathrm{a}}$ & $63.0^{\mathrm{b}}$ \\
\hline & Binomial test & $0.0000 *$ & $0.0000 *$ & $0.0105^{*}$ \\
\hline \multirow[t]{3}{*}{ Rainwater harvesting } & Yes & $92.3^{\mathrm{a}}$ & $96.3^{\mathrm{a}}$ & $50.0^{\mathrm{b}}$ \\
\hline & No & $7.7^{\mathrm{a}}$ & $3.7^{\mathrm{a}}$ & $50.0^{\mathrm{b}}$ \\
\hline & Binomial test & $0.0000 *$ & $0.0000 *$ & $0.3822 *$ \\
\hline
\end{tabular}

Each subscript letter denotes a subset of community categories whose row proportions do not differ significantly from each other at the .05 level. Binomial test analysis of yes and no responses by respondents *significant at $0.05 ;$ ns=not significant at 0.05

Shifting the crop planting period to coincide with the onset of the rainy season in response to erratic rainfall was more common in Mutale (78\%) than Makhado (51.6\%) and Thulamela (38\%) municipalities. This was not surprising given the fact that Mutale is the driest part of Vhembe District. As a result, the residents of Mutale municipality are more exposed to direct and indirect consequences of erratic rainfall. Shifting the planting and transplanting seasons to cope with erratic rainfall has also been observed in the Mruthyunjaya and Selvaraja (2002) study in rural communities of Coastal Orissa, India. However, the effectiveness and efficiency of this strategy depends on the households' continued access to climate information required to make decisions. The information enables local people to schedule their planting operation in sync with prevailing climatic conditions.

Growing crops on stream banks was not significantly practiced in the three municipalities of Vhembe district. This was not surprising because there were no streams in most of the villages that were studied. In the villages where there were streams, crops were mostly plated in inaccessible terrains located far away from dwelling places. 
Subsistence use and trade in non-timber forest products (NTFPs) were not common practices in all the three municipalities. In general, these strategies are not associated with the challenges of climate variability and change. This explains why it was not a significant coping strategy in the study communities. Another plausible explanation for the non-significant use of NTFPs as a coping strategy in the study communities could be the current poor development/organisation of the informal forest sector. As a result, the people did not derive maximum benefit from the sector, thus discouraging widespread participation in trade in forest products in the study communities.

Approximately, $50 \%$ to $96.3 \%$ of the household representatives indicated that rainwater harvesting was one of the coping strategies they relied on. Rain water harvesting has also been observed as a popular coping strategy among rural communities in Nigeria (Boon and Ahenkan, 2012) and Ghana (Ajani et al., 2013). The effectiveness and sustainability of rain water harvesting techniques often depend on the volume of the storage tanks that households install. Because of widespread poverty in the study communities, most households found it difficult to effectively utilise this strategy. The residents either installed small tanks or did not have storage tanks at all. They relied on few large containers they owned. As a result of this challenge, these households stored water that lasted a few days. This means that this strategy is inappropriate for dealing with prolonged, erratic rainfall events. Type of housing also affects the effectiveness of rain water harvesting. Most often, people living in a traditional thatched roof mud houses cannot effectively adopt this strategy. In general, lack of access to credit is a major constraint to coping and adaptation to climate change in rural communities of most African countries (Bryan et al., 2010; Chigavazira, 2012; Tembo, 2013).

Planting drought-resistant crops such as water melons and use of dug out wells for irrigation were some of the strategies used to cope with erratic rainfall. Perlis (2009) reported similar results from research on risks such as excessive or low rainfall, drought and crop failure in rural communities in the Chad Republic. The growing of crops that are resistant to erratic rainfall and drought challenges serves as a safety measure for facilitating household livelihood resilience. The effectiveness of this strategy is largely dependent on the financial capacity of households and their access to improved planting stock.

\subsubsection{Coping strategies for dealing with drought event}

There was a link between occurrence and coping with erratic rainfall and drought events in the communities in Vhembe district where this study was undertaken. The coping strategies are presented in Table 3.

Improved water storage and reuse were common in all the three municipal areas where the current study was carried out. In general, more people tended to conserve and reuse water in areas that experienced poor water supply. The storage and reuse enabled households to improve efficiency of water use and management in the communities. It is crucial to promote such strategies such that it becomes a regular practice.

Just as observed in the case of households' coping strategies to erratic rainfall, the dependence on use and trade in NTFPs as a strategy for coping with drought was uncommon. Nevertheless, it appeared there was potential for improved use and trade in NTFPs as an alternative strategy for strengthening household resilience to climate change-induced challenges. Furthermore, it was observed that crop irrigation was significantly practiced in Makhado municipality only. Presumably, this was so because of varying levels of functionality of water supply facilities in the municipalities. Migration to urban areas in search for work opportunities in response to drought challenges was not a common coping strategy in the studied communities. The non-significant practice of rural-urban migration as a coping strategy was an opportunity worth exploiting in the quest for local development. For example, because of limited outward migration, it was likely that developmental projects such as forest plantations established in the communities would not experience severe shortage of labour. 
Table 3: Common strategies forest-based rural households in Vhembe District of South Africa used to cope with drought

\begin{tabular}{|c|c|c|c|c|}
\hline \multirow[t]{2}{*}{ Coping strategies } & \multirow[t]{2}{*}{ Responses } & \multicolumn{3}{|c|}{ Communities } \\
\hline & & Makhado & Mutale & Thulamela \\
\hline \multirow[t]{3}{*}{ Improve water storage } & Yes & $77.1^{\mathrm{a}}$ & $100.0^{b}$ & $21.0^{\mathrm{c}}$ \\
\hline & No & $22.9^{\mathrm{a}}$ & $0.0^{\mathrm{b}}$ & $79.0^{\mathrm{c}}$ \\
\hline & Binomial test & $0.0000^{*}$ & $0.0000 *$ & $0.0000 *$ \\
\hline \multirow[t]{3}{*}{ Water reuse } & Yes & $82.1^{\mathrm{a}}$ & $98.2^{\mathrm{b}}$ & $56.0^{\mathrm{c}}$ \\
\hline & No & $17.9^{\mathrm{a}}$ & $1.8^{\mathrm{b}}$ & $44.0^{\mathrm{c}}$ \\
\hline & Binomial test & $0.0000 *$ & $0.0000 *$ & $0.0967^{\mathrm{ns}}$ \\
\hline \multirow{3}{*}{$\begin{array}{l}\text { Depended on use and marketing of non-timber } \\
\text { forest product }\end{array}$} & Yes & $43.6^{\mathrm{a}}$ & $49.1^{\mathrm{a}}$ & $12.0^{\mathrm{b}}$ \\
\hline & No & $56.4^{\mathrm{a}}$ & $50.9^{\mathrm{a}}$ & $88.0^{\mathrm{b}}$ \\
\hline & Binomial test & $0.2342^{\mathrm{ns}}$ & $0.4624^{\mathrm{ns}}$ & $0.0000 *$ \\
\hline \multirow[t]{3}{*}{ Migration to urban areas for work } & Yes & $15.9^{\mathrm{a}}$ & $7.3^{\mathrm{a}}$ & $6.0^{\mathrm{a}}$ \\
\hline & No & $84.1^{\mathrm{a}}$ & $92.7^{\mathrm{a}}$ & $94.0^{\mathrm{a}}$ \\
\hline & Binomial test & $0.0000 *$ & $0.0000 *$ & $0.0000 *$ \\
\hline \multirow{3}{*}{$\begin{array}{l}\text { Increase water capture e.g. borehole water, rain } \\
\text { water harvest etc. }\end{array}$} & Yes & $73.9^{\mathrm{a}}$ & $87.3^{\mathrm{b}}$ & $22.8^{\mathrm{c}}$ \\
\hline & No & $26.1^{\mathrm{a}}$ & $12.7^{\mathrm{b}}$ & $77.2^{\mathrm{c}}$ \\
\hline & Binomial test & $0.0000^{*}$ & $0.0000 *$ & $0.0000 *$ \\
\hline \multirow{3}{*}{$\begin{array}{l}\text { Water rationing e.g. reduce water use per } \\
\text { person per day }\end{array}$} & Yes & $96.2^{\mathrm{a}}$ & $96.3^{\mathrm{a}}$ & $76.0^{\mathrm{b}}$ \\
\hline & No & $3.8^{\mathrm{a}}$ & $3.7^{\mathrm{a}}$ & $24.0^{\mathrm{b}}$ \\
\hline & Binomial test & $0.0000 *$ & $0.0000 *$ & $0.0000 *$ \\
\hline \multirow[t]{3}{*}{ Switch to planting drought resistant crop } & Yes & $84.0^{\mathrm{a}}$ & $98.2^{\mathrm{b}}$ & $31.7^{\mathrm{c}}$ \\
\hline & No & $16.0^{\mathrm{a}}$ & $1.8^{\mathrm{b}}$ & $68.3^{\mathrm{c}}$ \\
\hline & Binomial test & $0.0000 *$ & $0.0000 *$ & $0.0002 *$ \\
\hline \multirow[t]{3}{*}{ Cropping around streams } & Yes & $59.0^{\mathrm{a}}$ & $11.0^{\mathrm{b}}$ & $21.0^{\mathrm{b}}$ \\
\hline & No & $40.4^{\mathrm{a}}$ & $89.0^{\mathrm{b}}$ & $79.0^{\mathrm{b}}$ \\
\hline & Binomial test & $0.0038^{*}$ & $0.0000 *$ & $0.0000 *$ \\
\hline \multirow[t]{3}{*}{ Crop irrigation } & Yes & $66.9^{\mathrm{a}}$ & $37.6^{\mathrm{b}}$ & $28.0^{\mathrm{b}}$ \\
\hline & No & $33.1^{\mathrm{a}}$ & $62.4^{\mathrm{b}}$ & $72.0^{\mathrm{b}}$ \\
\hline & Binomial test & $0.0000 *$ & $0.0089 *$ & $0.0000 *$ \\
\hline
\end{tabular}

Each subscript letter denotes a subset of community categories whose row proportions do not differ significantly from each other at the .05 level. Binomial test analysis of yes and no responses by respondents *significant at 0.05 ; ns=not significant at 0.05

\subsubsection{Coping strategies for dealing with extreme temperature}

Extremely high temperatures were recorded with varying consequences on lives and livelihood of residents of Makhado, Mutale and Thulamela municipalities. The strategies that the people developed to cushion themselves from the extreme temperatures are shown in Table 4.

More than $70 \%$ of respondents confirmed that members of their households either planted or retained trees around their homes and farms to provide shade. This helped to combat intense sunshine and associated extremely high temperatures that were expected to induce heat stress. As shown in Table 4, this practice was common in all the three municipal areas. The results confirm those of other author scholars who indicated that it was widely practiced in many developing countries. For example, Pramova et al. (2012) observed this practice in rural communities of Malawi, Zambia and also South Africa. Other than providing shade, retaining trees on farms and around the house also ensured that cultural, ecological and economic benefits that add to household resilience and adaptive capacity are enjoyed (Robledo et al., 2012).

Coping strategies such as staying in-doors to reduce the number of hours spent carrying out farming activities, as reported in Makhado and Mutale municipalities, result in loss of productive time and inability to take advantage of livelihood improvement opportunities. Consequently, it hinders the growth of the household economy. Because of this, it can be concluded that this is not a sustainable coping strategy. 
Table 4: Common strategies forest-based rural households' in Vhembe District of South Africa used to cope with extreme temperatures

\begin{tabular}{lllll}
\hline \multicolumn{1}{c}{ Coping strategies } & \multicolumn{2}{c}{ Responses } & \multicolumn{3}{c}{ Communities } \\
\cline { 3 - 5 } & & \multicolumn{1}{c}{$\begin{array}{c}\text { Makhado } \\
(\boldsymbol{\%})\end{array}$} & $\begin{array}{c}\text { Mutale } \\
(\%)\end{array}$ & $\begin{array}{c}\text { Thulamela } \\
(\%)\end{array}$ \\
\hline Plant trees on farm to shade crop & Yes & $73.2^{\mathrm{a}}$ & $97.2^{\mathrm{b}}$ & $33.0^{\mathrm{c}}$ \\
& No & $26.8^{\mathrm{a}}$ & $2.8^{\mathrm{b}}$ & $67.0^{\mathrm{c}}$ \\
& Binomial test & $0.0000^{*}$ & $0.0000^{*}$ & $0.0004^{*}$ \\
Plant trees around house to provide shade & Yes & $98.1^{\mathrm{a}}$ & $99.1^{\mathrm{a}}$ & $89.0^{\mathrm{b}}$ \\
& No & $1.9^{\mathrm{a}}$ & $0.9^{\mathrm{a}}$ & $11.0^{\mathrm{b}}$ \\
Stay in-door (reduced the number of hours & Yes & $0.0000^{*}$ & $0.0000^{*}$ & $0.0000^{*}$ \\
spent on farming activity) & No & $64.7^{\mathrm{a}}$ & $96.3^{\mathrm{b}}$ & $44.0^{\mathrm{c}}$ \\
& Binomial test & $35.3^{\mathrm{a}}$ & $3.7^{\mathrm{b}}$ & $56.0^{\mathrm{c}}$ \\
Bought air cooling appliance e.g. fan etc. & Yes & $0.0003^{*}$ & $0.0000^{*}$ & $0.2421^{\mathrm{ns}}$ \\
& No & $80.3^{\mathrm{a}}$ & $99.1^{\mathrm{b}}$ & $51.0^{\mathrm{c}}$ \\
& Binomial test & $0.0000^{*}$ & $0.0000^{*}$ & $0.4602^{\mathrm{ns}}$ \\
\hline
\end{tabular}

Each subscript letter denotes a subset of community categories whose row proportions do not differ significantly from each other at the .05 level. Binomial test analysis of yes and no responses by respondents *significant at 0.05; ns=not significant at 0.05

\subsubsection{Current role of forest in households coping strategy}

Empirical evidence generated in this study revealed that forests and forest products played a wide range of roles in households' response to climate variability and extreme weather events. Firewood, wild fruits and food for example wild berries, thatching grass (Hyparrhenia filipendula), wild vegetables such as green amaranth (Amaranthus hybridus), and game meat, edible wild insect species in particular Mopani worms (Gonimbrasia belina), locusts and white termites were some of the commonest forest products that the local households relied on to deal with climate variability and change. As has been revealed already, trees were also planted and retained around homesteads and croplands. The common tree species that were planted or retained included fruit bearing species such as mango (Mangifera indica), avocado (Persea americana); exotic timber species such as eucalyptus and pine, and indigenous species for example Mopane (Colophospermum mopane) and those used for firewood. Subsistence use and trade in forest products in the studied communities was viewed more as a livelihood strategy needed to enhance wellbeing. This means that they were less regarded as a strategy to combat the effects of climate change and variability challenges. These findings were in stark contrast to the situation in several rural communities in West Africa in which subsistence use and trade in forest products were regarded as strategies for coping with climate variability and change (Belcher et al., 2007).

Forests and associated products are commonly known for providing key goods and services that serve as safety nets to counter climate variability and extreme weather hazards. This makes them crucial assets for rural-based households. For instance, Paumgarten and Shackleton (2011) observed that 70\% of households in the Eastern Cape and Limpopo provinces of South Africa used NTFPs to help cope with shocks, including those resulting from climatic variability. In addition, tree planting is widely used in many developing countries to cope with climate variability and change events. For example, in Ghana, farmers planted trees, including commercial timber species, on their farms to protect their crops from intense sunshine and also enhance their livelihood (Boon and Ahenkhan 2012). In Kenya, Bryan et al. (2011) observed that about 39\% of respondents in their study identified tree planting as their most desired adaptation strategy. Similarly, rural communities in the Congo Basin were observed to use forests extensively to cope with the challenges of climate variability such as delayed onset of the rainy season (Belcher et al., 2007). However, in the current study in Vhembe district, forest products did not play a prominent role in this regard. Musyoki (2012) attributes this to poor access of forest products to markets and also the poor organisation of the informal sector. 
In the current study, the influence of access to markets on popularisation of forest-based coping strategies and its implication for the development of enterprises in this sector were examined. Analysis of association between satisfaction with access to market and adoption of forest-based coping practices gave mixed results. Only $10 \%$ of the respondents were satisfied with access or nearness to markets for forest products as an opportunity that they could take advantage of to counter the effects of erratic rainfall and extreme drought events. Use of forest products as a coping strategy was not significantly associated ( $>0.05)$ with erratic rainfall and extreme drought events. However, there was a significant association $(\mathrm{p}<0.05)$ between satisfaction with access or nearness to local markets and use of forest products to cope with effect of extreme temperatures. Thus, it was possible to maximize the benefit of using forests to enhance resilience of household livelihood. This means, also, that there is scope for adopting coping strategies that promoted the domestication of forest products, in particular NTFPs. According to Musyoki (2012), promotion of domestication of NTFPs is an important strategy for promoting forest entrepreneurship, green growth and enhancement of forest-based livelihood in the studied communities. These are all essential components of forest-based adaptation initiatives for strengthening livelihood resilience to climate change and variability challenges in the rural areas.

Table 5: Challenges or barriers to strategies used to cope with climate variability and change in some parts of Vhembe district of South Africa

\begin{tabular}{|c|c|c|c|c|}
\hline \multirow[t]{2}{*}{ Challenges } & \multirow[t]{2}{*}{ Response } & \multicolumn{3}{|c|}{ Municipality } \\
\hline & & $\begin{array}{c}\text { Makhado } \\
(\%)\end{array}$ & $\begin{array}{c}\text { Mutale } \\
(\%)\end{array}$ & Thulamela (\%) \\
\hline \multirow{3}{*}{$\begin{array}{l}\text { Insufficient information about weather or long- } \\
\text { term climate change }\end{array}$} & Yes & $87.0^{\mathrm{a}}$ & $75.0^{b}$ & $45.0^{\mathrm{c}}$ \\
\hline & No & $13.0^{\mathrm{a}}$ & $25.0^{\mathrm{b}}$ & $55.0^{\mathrm{c}}$ \\
\hline & Binomial test & $0.0000^{*}$ & $0.0000 *$ & $0.3086^{\mathrm{ns}}$ \\
\hline \multirow{3}{*}{$\begin{array}{l}\text { Lack of knowledge/skill about appropriate } \\
\text { coping strategy }\end{array}$} & Yes & $80.4^{\mathrm{a}}$ & $74.3^{\mathrm{a}}$ & $41.0^{\mathrm{b}}$ \\
\hline & No & $19.6^{\mathrm{a}}$ & $25.7^{\mathrm{a}}$ & $59.0^{\mathrm{b}}$ \\
\hline & Binomial test & $0.0000^{*}$ & $0.0000 *$ & $0.0666^{\mathrm{ns}}$ \\
\hline \multirow[t]{3}{*}{ Lack of money or access to credit } & Yes & $87.0^{\mathrm{a}}$ & $80.6^{\mathrm{a}, \mathrm{b}}$ & $71.0^{\mathrm{b}}$ \\
\hline & No & $13.0^{\mathrm{a}}$ & $19.4^{\mathrm{a}, \mathrm{b}}$ & $29.0^{\mathrm{b}}$ \\
\hline & Binomial test & $0.0000 *$ & $0.0000 *$ & $0.0000 *$ \\
\hline \multirow[t]{3}{*}{ Unavailability of desired forest product } & Yes & $76.6^{\mathrm{a}}$ & $76.9^{\mathrm{a}}$ & $41.0^{\mathrm{b}}$ \\
\hline & No & $23.4^{\mathrm{a}}$ & $23.1^{\mathrm{a}}$ & $59.0^{\mathrm{b}}$ \\
\hline & Binomial test & $0.0000 *$ & $0.0000 *$ & $0.0967^{\mathrm{ns}}$ \\
\hline \multirow[t]{3}{*}{ Poor of access to market } & Yes & $79.9^{\mathrm{a}}$ & $72.2^{\mathrm{a}, \mathrm{b}}$ & $61.0^{\mathrm{b}}$ \\
\hline & No & $20.1^{\mathrm{a}}$ & $27.8^{\mathrm{a}, \mathrm{b}}$ & $39.0^{\mathrm{b}}$ \\
\hline & Binomial test & $0.0000 *$ & $0.0000 *$ & $0.0105^{*}$ \\
\hline \multirow[t]{3}{*}{ Change of farming practice } & Yes & $85.1^{\mathrm{a}}$ & $75.0^{\mathrm{a}}$ & $50.5^{\mathrm{b}}$ \\
\hline & No & $14.9^{\mathrm{a}}$ & $25.0^{\mathrm{a}}$ & $49.5^{\mathrm{b}}$ \\
\hline & Binomial test & $0.0000 *$ & $0.0000 *$ & $0.3822^{\mathrm{ns}}$ \\
\hline \multirow{3}{*}{$\begin{array}{l}\text { Inadequate supply of improved planting } \\
\text { materials }\end{array}$} & Yes & $79.2^{\mathrm{a}}$ & $75.9^{\mathrm{a}}$ & $44.0^{\mathrm{b}}$ \\
\hline & No & $20.8^{\mathrm{a}}$ & $24.1^{\mathrm{a}}$ & $56.0^{\mathrm{b}}$ \\
\hline & Binomial test & $0.0000 *$ & $0.0000 *$ & $0.2421^{\mathrm{ns}}$ \\
\hline \multirow{3}{*}{$\begin{array}{l}\text { Erosion of traditional skills and knowledge } \\
\text { amongst younger generation }\end{array}$} & Yes & $81.2^{\mathrm{a}}$ & $75.9^{\mathrm{a}}$ & $53.0^{\mathrm{b}}$ \\
\hline & No & $18.8^{\mathrm{a}}$ & $24.1^{\mathrm{a}}$ & $47.0^{\mathrm{b}}$ \\
\hline & Binomial test & $0.0000^{*}$ & $0.0000^{*}$ & $0.1841^{\mathrm{ns}}$ \\
\hline \multirow{3}{*}{ Breakdown in communities' communal nature } & Yes & $77.9^{\mathrm{a}}$ & $74.1^{\mathrm{a}}$ & $48.0^{\mathrm{b}}$ \\
\hline & No & $22.1^{\mathrm{a}}$ & $25.9^{\mathrm{a}}$ & $52.0^{\mathrm{b}}$ \\
\hline & Binomial test & $0.0000 *$ & $0.0000 *$ & $0.5398^{\mathrm{ns}}$ \\
\hline
\end{tabular}

Each subscript letter denotes a subset of community categories whose column proportions do not differ significantly from each other at the .05 level. Binomial test analysis of yes and no responses by respondents *significant at 0.05; ns=not significant at 0.05

\subsection{Perceived barriers or challenges to coping strategies}

In this study, the respondents identified various issues that restricted implementation of effective coping strategies in dealing with climate variability and extreme weather events. It was observed that some coping strategies were widely used, while others were only relied on sparingly. In adition, they 
yielded varying outcomes on household resilience. As shown in Table 5, there were many challenges that hindered success of commonly used coping strategies.

Poor access to markets and insufficient money and/or lack of access to credit were pronounced in all the three municipalities. More than $60 \%$ of the respondents identified these challenges as impediments to adopting strategies for coping with climate variability and change. This problem was slightly more pronounced in Makhado than in Mutale and Thulamela municipalities. Probably, this could be attributed to high unemployment rates and the difficulty of securing sufficient credit. Access to credit and markets severely limit household adaptive capacity. The need for funding to improve coping strategies cannot be underestimated. Additionally access to markets enables households to trade their produce in order to procure essential products needed to improve their resilience to climate risks (Egyir et al., 2015).

The inadequate supply of improved planting materials was another major challenge identified, especially in Makhado (79.2\%) and Mutale (75.9\%) municipalities. However, this was not a significant ( $p>0.05)$ challenge in Thulamela municipality. Access to improved planting materials such as drought-tolerant varieties can greatly improve rural households' livelihood resilience to erratic rainfall and drought (Quinn et al., 2011).

The lack or insufficient knowledge of traditional and/or modern coping strategies was widely identified as a challenge that curtailed the ability to effectively combat the negative effects of climate variability and change. Among the challenges that the respondents cited were insufficient locationspecific information about weather or long-term climatic conditions, inadequate knowledge and skills to implement modern coping strategies such as switching to cultivation of drought-resistant crops, and erosion of traditional skills and knowledge resulting in the younger generation being ignorant of it. The lack or insufficient knowledge to aid effective and efficient implementation of traditional and/or modern coping strategies has also been reported in other rural communities in Africa and Asia (Nzuma et al., 2010; Chigavazira, 2012; Wilk et al., 2012). The lack of information on how to improve traditional coping strategies so as to make them relevant for climate change adaptation can exacerbate rural communities' vulnerability. It is also important to package climate information in a manner that is tailored to the need of forest-based rural communities. In the current study, the respondents were interested in the relevance of climate information to their livelihood improvement strategy. It seemed this was one of the reasons why most of the climate information that respondents harnessed was insignificant contributing to the improvement of households' livelihood practices for combating climate change challenges.

It was reported that the communities in the studied areas of Vhembe district tended to be more individualistic in their response to communal challenges. This contrasted past practices when communal challenges were approached collectively. The unavailability of desired forest products in coping with climate variability and change was also highlighted. The respondents opined that people's individualistic approach to forest use and uncontrolled management of communal resources primarily caused the scarcity of forest products. In support of this view, local traditional leaders confirmed that they no longer had regulatory control over forest product use and management in the communities. This has also been observed among rural communities in the Offin river basin of Ghana (Gyampoh et al., 2009).

Most of the challenges reported in this study are synergistic, implying that a common approach can be adopted to improve the adaptive capacity of people. For example, inadequate supply of improved planting materials is closely related with lack of access to credit facilities. Wilk et al. (2012) made similar observations among commercial farmers in South Africa. In the latter study, access to finance was reported to be contributing to farmers' resilience to drought because it enabled them to spend money on drought-resistant seeds, fertilizers and irrigation, among other inputs. Moreover, access to credit often enabled households to diversify into non forest-based livelihood activities and helped reduce their sensitivity to climate variability and extreme weather events. 


\subsection{Attributes of households adaptive capacity}

The demographic characteristics of the communities in Vhembe district and how they influenced the strategies that households used to cope with adverse weather and climate change are presented. Although the households adopted diverse strategies for coping with the effect of climate variability and change, there were mixed results. Differences in the adaptive capacities of households to positively respond to adverse effects of climate variability and change depended on various factors, including institutional resources, social support and human capital. These are further elaborated below.

\subsubsection{Institutional Resources}

Institutional resources are known to considerably impact on households' coping practices and adaptive capacities in response to climate change and variability. It is shown in Table 6 that remarkably high proportions of respondents in Mutale (74.4\%), Thulamela (59\%) and Makhado (52.9\%) municipalities were either very dissatisfied or dissatisfied with water supply facilities in their areas. The respective proportions of respondents who were also either very dissatisfied or dissatisfied with access or closeness to markets were $90.9 \%$ for Mutale followed by Makhado $(67.3 \%)$ and Thulamela $(60 \%)$ municipalities. The levels of satisfaction with communication serves also varied across the municipalities. The proportions of respondents who were either very dissatisfied or dissatisfied were $70.3 \%, 67.7 \%$ and $35.6 \%$ for Makhado, Mutale and Thulamela municipalities, respectively.

Table 6: Demographic factors influencing adaptive capacity in some areas of Vhembe district in South Africa

\begin{tabular}{|c|c|c|c|c|}
\hline \multirow{2}{*}{$\begin{array}{l}\text { Attributes of households } \\
\text { adaptive capacity }\end{array}$} & \multirow[t]{2}{*}{ Response } & \multicolumn{3}{|c|}{ Proportion of respondents (\%) in } \\
\hline & & $\begin{array}{l}\text { Makhado }(n \\
=156)\end{array}$ & $\begin{array}{l}\text { Mutale } \\
(n=110)\end{array}$ & $\begin{array}{c}\text { Thulamela (n } \\
=100)\end{array}$ \\
\hline \multirow[t]{5}{*}{ Water supply services } & Very dissatisfied & $16.6^{\mathrm{a}}$ & $60.6^{\mathrm{b}}$ & $33.0^{\mathrm{c}}$ \\
\hline & Dissatisfied & $36.3^{\mathrm{a}}$ & $13.8^{\mathrm{b}}$ & $26.0^{\mathrm{a}, \mathrm{b}}$ \\
\hline & Neither satisfied nor dissatisfied & $0.6^{\mathrm{a}}$ & $0.9^{\mathrm{a}}$ & $1.0^{\mathrm{a}}$ \\
\hline & Satisfied & $28.0^{\mathrm{a}}$ & $10.1^{\mathrm{b}}$ & $16.0^{\mathrm{a}, \mathrm{b}}$ \\
\hline & Very satisfied & $18.5^{\mathrm{a}}$ & $14.7^{\mathrm{a}}$ & $24.0^{\mathrm{a}}$ \\
\hline \multirow[t]{5}{*}{ Access or closeness to market } & Very dissatisfied & $25.0^{\mathrm{a}}$ & $68.2^{\mathrm{b}}$ & $23.0^{\mathrm{a}}$ \\
\hline & Dissatisfied & $42.3^{\mathrm{a}}$ & $22.7^{\mathrm{b}}$ & $37.0^{\mathrm{a}, \mathrm{b}}$ \\
\hline & Neither satisfied nor dissatisfied & $2.6^{\mathrm{a}}$ & $0.9^{\mathrm{a}}$ & $0.0^{\mathrm{a}}$ \\
\hline & Satisfied & $25.0^{\mathrm{a}}$ & $3.6^{\mathrm{b}}$ & $11.0^{\mathrm{b}}$ \\
\hline & Very satisfied & $5.1^{\mathrm{a}}$ & $4.5^{\mathrm{a}}$ & $29.0^{\mathrm{b}}$ \\
\hline \multirow[t]{5}{*}{ Communication services } & Very dissatisfied & $12.2^{\mathrm{a}}$ & $51.4^{\mathrm{b}}$ & $10.0^{\mathrm{a}}$ \\
\hline & Dissatisfied & $58.1^{\mathrm{a}}$ & $16.3^{\mathrm{b}}$ & $25.6^{\mathrm{a}, \mathrm{b}}$ \\
\hline & Neither satisfied nor dissatisfied & $5.1^{\mathrm{a}}$ & $0.0^{\mathrm{b}}$ & $1.0^{\mathrm{a}, \mathrm{b}}$ \\
\hline & Satisfied & $40.4^{\mathrm{a}}$ & $14.7^{\mathrm{b}}$ & $24.0^{\mathrm{b}}$ \\
\hline & Very satisfied & $42.7^{\mathrm{a}}$ & $29.9^{b}$ & $27.4^{\mathrm{c}}$ \\
\hline
\end{tabular}

Each subscript letter denotes a subset of Community categories whose column proportions do not differ significantly from each other at the .05 level.

The results of the investigation of the relationship between satisfaction with institutional resources, water supply facilities and household adoption of various strategies to cope with climate variability are presented in Table 7 
Table 7: Influence of satisfaction with water supply facilities on adoption of coping strategies for climate variability in some areas of Vhembe district in South Africa

\begin{tabular}{cccccc}
\hline Parameter & DF & Estimate & $\begin{array}{c}\text { Standard } \\
\text { Error }\end{array}$ & $\begin{array}{c}\text { Wald } \\
\text { Chi-Square }\end{array}$ & Pr > ChiSq \\
\hline Intercept & 1 & 0.1312 & 0.1895 & 0.4791 & 0.4888 \\
Off-farm work & 1 & -0.5900 & 0.2358 & 6.2600 & 0.0123 \\
Cropping around streams & 1 & 0.5265 & 0.2493 & 4.4609 & 0.0347 \\
\hline
\end{tabular}

It is indicated in Table 7 that satisfaction with water supply in a community decreased $(p<0.05)$ the likelihood that the household would adopt off-farm activity as a coping strategy by 0.59 . In addition, satisfaction with water supply facilities in a community increased by $0.52(\mathrm{p}<0.05)$ the likelihood that a household would adopt cropping around streams as a coping strategy. This implies that improved water supply facility has a positive impact on the resilience of a household's crop farming strategy. Ishaya and Abaje (2008) reported that access to improved functioning of institutional resources enhanced farmers' adaptive capacity. Improving institutional facilities in a community within the framework of climate change adaptation positively influences the realisation of sustainable development, and also reduces rural-urban migration. Therefore, in support of Goldman and Riosmen (2013), it can be posited that sound institutional facilities serve as a catalyst for promoting the adoption of effective coping strategies among rural households.

\subsubsection{Social Support}

The many social support mechanisms that existed in the studied communities are shown in Table 8 . They provided assistance that helped local people cope with the vagaries emanating from climate variability and change.

Table 8: Functioning social support group in the study communities

\begin{tabular}{|c|c|c|c|c|}
\hline \multirow[t]{2}{*}{ Social group } & \multirow[t]{2}{*}{ Response } & \multicolumn{3}{|c|}{ Municipality } \\
\hline & & $\begin{array}{c}\text { Makhado } \\
(\%)\end{array}$ & $\begin{array}{c}\text { Mutale } \\
(\%)\end{array}$ & Thulamela (\%) \\
\hline Family members living outside & Yes & $88.4^{\mathrm{a}}$ & $70.6^{\mathrm{b}}$ & $65.0^{\mathrm{b}}$ \\
\hline community & $\begin{array}{l}\text { No } \\
\text { Binomial test }\end{array}$ & $\begin{array}{l}11.6^{\mathrm{a}} \\
0.0000^{*}\end{array}$ & $\begin{array}{l}29.4^{\mathrm{b}} \\
0.0000^{*}\end{array}$ & $\begin{array}{l}35.0^{\mathrm{b}} \\
0.0000^{*}\end{array}$ \\
\hline Neighbours & $\begin{array}{l}\text { Yes } \\
\text { No }\end{array}$ & $\begin{array}{l}87.1^{\mathrm{a}} \\
12.9^{\mathrm{a}}\end{array}$ & $\begin{array}{l}82.6^{\mathrm{a}} \\
17.4^{\mathrm{a}}\end{array}$ & $\begin{array}{l}39.0^{\mathrm{b}} \\
61.0^{\mathrm{b}}\end{array}$ \\
\hline Local community organisation & $\begin{array}{l}\text { Binomial test } \\
\text { Yes }\end{array}$ & $\begin{array}{l}0.0000^{*} \\
79.4^{\mathrm{a}}\end{array}$ & $\begin{array}{l}0.0000^{*} \\
67.0^{\mathrm{a}}\end{array}$ & $\begin{array}{l}0.0000^{*} \\
20.0^{\mathrm{b}}\end{array}$ \\
\hline & $\begin{array}{l}\text { No } \\
\text { Binomial test }\end{array}$ & $\begin{array}{l}20.6^{\mathrm{a}} \\
0.0000^{*}\end{array}$ & $\begin{array}{l}33.0^{\mathrm{a}} \\
0.0001 *\end{array}$ & $\begin{array}{l}80.0^{\mathrm{b}} \\
0.0000^{*}\end{array}$ \\
\hline The municipality & $\begin{array}{l}\text { Yes } \\
\text { No } \\
\text { Binomial test }\end{array}$ & $\begin{array}{l}83.2^{\mathrm{a}} \\
16.8^{\mathrm{a}} \\
0.0000^{*}\end{array}$ & $\begin{array}{l}50.9^{\mathrm{b}} \\
49.1^{\mathrm{b}} \\
0.4248^{\mathrm{ns}}\end{array}$ & $\begin{array}{l}51.0^{\mathrm{b}} \\
49.0^{\mathrm{b}} \\
0.5398^{\mathrm{ns}}\end{array}$ \\
\hline Provincial government & $\begin{array}{l}\text { Yes } \\
\text { No } \\
\text { Binomial test }\end{array}$ & $\begin{array}{l}63.9^{\mathrm{a}} \\
36.1^{\mathrm{a}} \\
0.0000^{*}\end{array}$ & $\begin{array}{l}54.6^{\mathrm{a}} \\
45.4^{\mathrm{a}} \\
0.1713^{\mathrm{ns}}\end{array}$ & $\begin{array}{l}8.9^{\mathrm{b}} \\
91.1^{\mathrm{b}} \\
0.0000^{*}\end{array}$ \\
\hline
\end{tabular}

Each subscript letter denotes a subset of Community categories whose column proportions do not differ significantly from each other at the .05 level. Binomial test analysis of yes and no responses by respondents *significant at 0.05 ; ns=not significant at 0.05

Family members, neighbours, and local community based organisations were reported to be providing significant assistance to households. However, the support that municipalities and provincial 
government departments provided was regarded not so important across all the studied communities. There is usually a concern that social support initiatives of either municipalities or provincial government departments are laden with political motives. Twomlow (2002) and David (2007) have also pointed out that political interests rather than the desire to cushion households against drought guides the launch governmental social support services.

The relationship between support from Family members, neighbours and local community-based organisations, and barriers to adoption of coping strategies at household level were investigated. There was a significant association $(\mathrm{p}<0.05)$ between assistance from neighbours and expression of difficulty in coping with climate variability and change. Apart from the challenge of lack of money or access to credit, which was not significant ( $p>0.05$ ), all other expressed challenges observed in this study were significantly associated with assistance from neighbours as a support group. In most cases, less than $14 \%$ of the respondents that enjoyed support from neighbours expressed difficulty in coping with climate variability and change. Thus, social support groups such as neighbours are crucial in helping households cope with climate variability and change challenges in their locality.

The influence of support from local community organisations on respondents' expressed difficulty in coping with climate variability and change is shown in Table 9. Only three out of nine challenges to adopting coping strategies to counter the effects of climate variability and change that respondents revealed were statistically important. This meant that the households that enjoyed support from local community-based organisations coped well with climate variability and change. Moreover, the lack or insufficient access to credit facilities was observed to have a negative relationship with support from local community-based organisations. The lack or insufficient information on climate variability and change events and inadequate supply of improved planting materials were the only challenges that were significantly associated with support from local community-based organisations. Thus, the support from local community-based organisations was important in ensuring that households effectively coped with climate variability and change.

Table 9: Effect of support from local community-based organisations on households' strategies for coping with climate variability and change in some parts of Vhembe district in South Africa

\begin{tabular}{|c|c|c|c|c|c|}
\hline Parameter & $\mathbf{D F}$ & Estimate & $\begin{array}{l}\text { Standard } \\
\text { Error }\end{array}$ & $\begin{array}{l}\text { Wald } \\
\text { Chi-Square }\end{array}$ & Pr > ChiSq \\
\hline Intercept & 1 & 2.4095 & 0.7873 & 9.3665 & 0.0022 \\
\hline $\begin{array}{l}\text { Lack or insufficient information on climate } \\
\text { variability and change event }\end{array}$ & 1 & 1.3450 & 0.3995 & 11.3336 & 0.0008 \\
\hline Lack or insufficient access to credit facility & 1 & -0.9353 & 0.4311 & 4.7073 & 0.0300 \\
\hline Inadequate supply of improved planting materials & 1 & 1.1964 & 0.3595 & 11.0737 & 0.0009 \\
\hline
\end{tabular}

According to Robledo et al. (2012), there are many examples of how social support groups affect the capability of communities to adapt to risks related to climate change. This view finds support from an earlier Valdivia et al. (2005) study, which revealed that informal non-monetary arrangements and social networks helped rural communities in Samoa to cope with storm damage. Social support groups such as local community-based organisations, neighbours, and family members have significant capacity to enhance collective action and use of group advantage to access other capitals in facilitating the resilience of people to climate variability and change.

\subsubsection{Human capital resources}

The human resources development significantly impacts on people's ability to adapt efficiently to climate change challenges (Striessnig et al., 2013). In the current study, the effect of human resources such as farming skills and highest level of education, on coping efficiency and adaptive capacity were examined. It was found that the lack of access to credit facilities and break down in the communal 
nature of society were not significantly associated $(\mathrm{p}>0.05)$ with farming skills. However, possession of farming skills was significantly associated $(p<0.05)$ with the other challenges that local households experienced, viz. erosion of traditional skills and knowledge amongst the younger generation and inadequate supply of improved planting materials. These results imply that in general, households with inherent farming skills are less likely to experience challenges in coping with climate variability and change than those without. Thus, investment in appropriate skilling of residents of the studied communities would considerably help reduce the possibility of households coping with climate change.

The relationships between respondents' highest level of education and choice of strategy and challenges experienced in attempts to cope with changes in climatic are presented in Table 10.

Table 10: The influence of respondents' level of education on choice of and challenges to coping strategies used to counter the negative effects of climate change

\begin{tabular}{|c|c|c|c|c|c|}
\hline $\begin{array}{l}\text { Dependent } \\
\text { variable }\end{array}$ & Independent variable & $\begin{array}{l}\text { Odds } \\
\text { ratio }\end{array}$ & Lower & Upper & P Value \\
\hline \multirow{10}{*}{$\begin{array}{l}\text { Possession of } \\
\text { academic } \\
\text { qualification }\end{array}$} & $\begin{array}{l}\text { Dependence on use and marketing of } \\
\text { NTFPs in response to erratic rainfall event }\end{array}$ & 2.622 & 1.080 & 6.361 & 0.033 \\
\hline & $\begin{array}{l}\text { Migration for work as a coping response to } \\
\text { extreme drought event }\end{array}$ & 0.177 & 0.063 & 0.502 & 0.001 \\
\hline & $\begin{array}{l}\text { Increased water capture in response to } \\
\text { extreme drought event }\end{array}$ & 2.189 & 1.059 & 4.525 & 0.035 \\
\hline & $\begin{array}{l}\text { Planting drought resistant crop in response } \\
\text { to extreme drought event }\end{array}$ & 2.681 & 1.092 & 6.580 & 0.031 \\
\hline & $\begin{array}{l}\text { Irrigation with stream water in response to } \\
\text { extreme drought event }\end{array}$ & 0.428 & 0.197 & 0.931 & 0.032 \\
\hline & $\begin{array}{l}\text { Reliance on social group in response to } \\
\text { flood event }\end{array}$ & 0.469 & 0.230 & 0.955 & 0.037 \\
\hline & $\begin{array}{l}\text { Sell of household asset in response to flood } \\
\text { event }\end{array}$ & 4.527 & 1.655 & 12.384 & 0.003 \\
\hline & Built flood control wall around homestead & 2.534 & 1.213 & 5.294 & 0.013 \\
\hline & $\begin{array}{l}\text { Possession of insufficient knowledge/skill } \\
\text { about appropriate coping option }\end{array}$ & 3.057 & 1.020 & 9.159 & 0.046 \\
\hline & $\begin{array}{l}\text { Breakdown in community's communal } \\
\text { nature }\end{array}$ & 0.313 & 0.098 & 0.998 & 0.050 \\
\hline
\end{tabular}

In the current study, it was observed that the level of educational attainment of an individual significantly impacted on his/her choice of coping strategy, including the types of challenges experienced during implementation. Out of eight coping strategies commonly used in response to erratic rainfall events, only two strategies are significantly practiced by more educated people. These are dependence on use and marketing of NTFPs. It was also observed that the more educated individuals relied mostly on four out of the nine coping strategies that could help counter the effects of extreme drought events. The more educated respondents tended to rely on non-forestry/agriculturebased livelihood strategies. Their strategies seemed to be few and more carefully selected, in contrast to their less educated counterparts who adopted multiple options.

The results presented above have highlighted that improving human capital in terms of skills and education would significantly reduce the challenges experienced in the studied communities as they attempt to cope with climate variability and change. According to David (2007), adequate human capital resources in terms of skills and educational level of the people allows for effective adaptation 
to climate change. Apart from improved human capital, this allows households to effectively utilise available traditional coping strategies and enable them to explore alternative coping strategies based on new information and innovativeness (Egyir et al., 2015). Given the uncertainty regarding understanding of the impact of specific manifestations of climate change on the people's lives and livelihood at rural community level in South Africa (Striessnig et al., 2013; Turpie and Visser, 2013), human capital improvement seems to be the most sensible option for improving rural households' resilience to risks of climate change. Striessnig et al. (2013) noted that improved human capital implied better access to, and ability to utilize relevant climate information for example seasonal prediction of drought. Improved human capital also often leads to higher incomes at individual and household levels, and greater economic growth within communities (Striessnig et al., 2013; Patt et al. 2010). This yields indirect benefits climate change mitigation through decoupling of livelihood strategies from unsustainable forest use and management practices (Muyoski, 2012).

\section{CONCLUSION AND RECOMMENDATION}

It was observed that forest-based rural communities in Vhembe district of South Africa employed a diverse range of strategies to cope with the biophysical and socioeconomic effects of climate variability and extreme weather events. In most cases the respondents tended to use strategies that did not direct impact negatively on their livelihood. Although some of the coping strategies were effective, affected households encountered many challenges. In general, the choice, effectiveness and efficiency of adopting any coping strategy depend on the nature of communities in question and their socioeconomic characteristics. Poor markets for forest products and poor organisation of the informal forest sectors in the communities hampered widespread adoption of forest-based coping strategies. Similarly, lack of access to credit was a major barrier to effective adoption of most of the coping strategies that the study communities used. Institutional facilities, social support groups and human capital resources are crucial for the success and choice of household's coping strategies. More specifically, the people's skills and educational levels are the major determinants of choice of coping strategies and efficiency of adopting them. Inadequate skills and lack of education among residents in the study communities limit their ability to participate in the formal economic sector. This relegates them to subsistence farming and reliance on forest products as a means of earning secure livelihoods. Given the uncertainty surrounding the precise manifestations of climate change in specific areas, it may be better to invest in skills development and acquisition of education to increase the peoples' flexibility and ability to adapt effectively to risks associated with climate change. It can be hypothesized from the current study that development of a suite of support initiatives such as facilitating access to credit facilities for the rural poor, developing markets for forest products particularly the under-exploited NTFPs, and enhancement of capacities of residents or rural areas to do things for themselves are likely to improve their ability to cope with the adverse effects of climate change.

\section{ACKNOWLEDGEMENTS}

The National Research Foundation of South Africa and South Africa Forestry Company Limited (SAFCOL) funded this research through the Forestry Postgraduate Programme at the University of Pretoria. The financial support enabled the first author to undertake this research as part of his $\mathrm{PhD}$ in Forestry studies. Special gratitude goes to the members and leaders of the communities in Mutale, Makhado and Thulamela municipalities where this study was conducted. The valuable inputs of Andries Masange and Frans Kanfer to this work are gratefully acknowledged. The authors would also 
like to indicate that the opinions expressed and conclusions arrived at, are those of the authors and are not of the sponsors.

\section{REFERENCES}

Adeniji-Oloukoi, G.,n, Urmilla,B., and Vadi, M. (2013). Households' coping strategies for climate variability related water shortages in Oke-Ogun region, Nigeria. Environmental Development $5,23-38$.

Adger, W.N., S. Agrawala, M.M.Q. Mirza, C. Conde, K. O’Brien, J. Pulhin, R. Pulwarty, B. Smit and K. Takahashi (2007): Assessment of adaptation practices, options, constraints and capacity. Climate Change 2007: Impacts, Adaptation and Vulnerability. Contribution of Working Group II to the Fourth Assessment Report of the Intergovernmental Panel on Climate Change, M.L. Parry, O.F. Canziani, J.P. Palutikof, P.J. van der Linden and C.E. Hanson, Eds., Cambridge University Press, Cambridge, UK, 717-743.

Ajani, E. N., Mgbenka, R. N., and Okeke, M. N. (2013). Use of Indigenous Knowledge as a Strategy for Climate Change Adaptation among Farmers in sub-Saharan Africa: Implications for Policy. Asian Journal of Agricultural Extension, Economics \& Sociology 2(1):, 23-40.

Alberini, A., Chiabai, A., and Muehlenbachs, L. (2006). Using expert judgment to assess adaptive capacity to climate change:evidence from a conjoint choice survey. Maryland, USA: University of Maryland.

Amisah, S.; Gyampoh, A.; Sarfo-Mensah, P.; Quagrainie, K. (2009). Livelihood trends in Response to Climate Change in Forest Fringe Communities of the Offin Basin in Ghana. Journal of Applied Science, Environment Management, Volume 13, Issue 2, 5-15.

Angela Andrade Pérez, Bernal Herrera Fernández and Roberto Cazzolla Gatti. (2010). Building Resilience to Climate Change: Ecosystem-based adaptation and lessons from the field. Gland, Switzerland: IUCN, International Union for Conservation of Nature.

Arnall, A. H. (2012). Understanding adaptive capacity at the local level in Mozambique. Maputo: Africa Climate Change Resilience Alliance (ACCRA) Mozambique Synthesis Report.

Belcher B., Ruíz-Pérez M., Achidiawan R. (2005). Global patterns and trends in the use and management of commercial NTFPs. World Dev. 33, 1435-1452 (doi:10.1016/j.worlddev.2004.10.007)

Berg, R. G. (2014). 4.1.1. SPSS Binomial Test. Retrieved June 18, 2015, from SPSS Tutorials: The Ultimate Guide for Mastering SPSS: http://www.spss-tutorials.com/spss-binomial-test/

Bethlehem J (2015) Applied Survey Methods: A statistical perspective. Retrieved March 11, 2015, from Weighting adjustment: http://www.applied-survey-methods.com/weight.html

Boon, E., and Ahenkan, A. (2012). Assessing Climate Change Impacts on Ecosystem Services and Livelihoods in Ghana: Case Study of Communities around Sui Forest Reserve. Journal of Ecosystem \& Ecography, S3:1-8. doi:10.4172/2157-7625.S3-001

Byrne, T. R. (2014). household adaptive capacity and current vulnerability to future climate change in rural Nicaragua. MSc Thesis. Alberta, Canada: University of Lethbridge.

CARE.2011. Understanding Vulnerability to Climate Change: Insights from Application of CARE's Climate Vulnerability and Capacity Analysis (CVCA) Methodology. CARE International Poverty, Environment and Climate Change Network (PECCN), 2011. Used with permission. 
CARE. (2014). Assessing Community Vulnerability and Adaptive Capacity to Climate Change in Dera and Farta Woredas of South Gonder Zone, Ethiopia. Addis Ababa: Global Water Initiative - East Africa.

Coulibaly, J.Y., Gbetibouo, G.A., Kundhlande, G., Sileshi, G.W., and Tracy L. Beedy, T.L. (2015). Responding to Crop Failure: Understanding Farmers' Coping Strategies in Southern Malawi. Sustainability 7, 1620-1636; doi:10.3390/su7021620

Chigavazira, B. M. (2012). Adapting to Climate Change to achieve Household Food Security: A Case Study of Small-Scale Farmers at Dzindi Smallholder Irrigation Scheme in the Limpopo Province of South Africa). Alice: MSc Thesis; University of Fort Hare.

Climate data for Polokwane". South African Weather Service. Archived from the original on March 4, 2012. Retrieved 7 March

David, S. G. T., Twyman, C., Osbahr, H., and Hewitson, B. (2007). Adaptation to climate change and variability: farmer responses to intra-seasonal precipitation trends in South Africa. Climatic Change, 83, 301-322.

Davidson D., Williamson T., and Parkins J.,. (2004). Understanding climate change risk and vulnerability in northern forest-based communities. Canadian Journal of Forest Research issue 33, 2252-2261.

Department of Environmental Affairs and Tourism: DEAT (2004) A national climate change response strategy for South Africa. Department of environmental affairs and tourism. Private Bag X447, Pretoria 0001. https://unfccc.int/files/meetings/seminar/application/pdf/sem_sup3_south_africa.pdf

Elrick-Barr, C. E., B. L. Preston, D. C. Thomsen, and T. F. Smith. 2014. Toward a new conceptualization of household adaptive capacity to climate change: applying a risk governance lens. Ecology and Society 19(4): 12. http://dx.doi.org/10.5751/ES-06745-190412

Egyir, I. S., Ofori, K., Antwi, G., and Ntiamoa-Baidu, Y. (2015). Adaptive Capacity and Coping Strategies in the Face of Climate Change: A Comparative Study of Communities around Two Protected Areas in the Coastal Savanna and Transitional Zones of Ghana. Journal of Sustainable Development; Vol. 8, No. 1, 1-15.

Fisher, M., Chaudhury, M., and McCusker, B. (2010). Do forests help rural households adapt to climate variability? Evidence from Southern Malawi. World Development 38:1241-1250. http://dx.doi.org/10.1016/j.worlddev.2010.03.005

Goldman, M. J., and Riosmen, F. (2013). Adaptive capacity in Tanzanian Maasailand: Changing strategies to cope with drought in fragmented landscapes. 588-597: Global Environmental Change 23.

Gyampoh, B. A., Nkrumah, K., Idinoba, M., and Nkem, J. N. (2009). Using traditional knowledge to cope with climate change in rural Ghana. In A. Perlis, Adapting to climate change, Unasylva No. 231/232, Vol. 60, 2009/1-2 (pp. 70-74). Rome: Food and Agriculture Organization of the United Nations.

Helgeson J., S. Dietz and S. Hochrainer-Stigler. (2013). Vulnerability to Weather Disasters: the Choice of Coping Strategies in Rural Uganda. Ecology and Society volume 18, Issue 2, 1-13.

Hughey, K.F.D., and Becken, S. (2014). Understanding climate coping as a basis for strategic climate change adaptation - The case of Queenstown-Lake Wanaka, New Zealand. Global Environmental Change $27,168-179$. 
ICIMOD .(2007). The melting Himalayas: Regional challenges and local impacts of climate change on mountain ecosystems and livelihoods, Technical Paper. Kathmandu: ICIMOD

IPCC. (2007). Africa. Climate Change 2007: Impacts, Adaptation and Vulnerability. Contribution of Working Group II to the Fourth Assessment Report of the Intergovernmental Panel on Climate Change, M.L. Parry, O.F. Canziani, J.P. Palutikof, P.J. van der Linden and C.E. Hanson, Eds., Cambridge University Press, Cambridge UK, 433-467.

Joerin, J., Shaw,R., Takeuchi,Y., and Krishnamurthy, R. (2012). Assessing community resilience to climate-related disasters in Chennai, India. International Journal of Disaster Risk Reduction $1,44-54$.

Lemos, M. C., Eakin, H., Nelson, D., and Engle, N . (2013). Building Capacity to Climate Change in Less Developed Countries. Michigan: School of Natural Resources and Environment.

Linkd Environmental Services. (2013). Draft Document: Climate Change Risk and Vulnerability Assessment for Rural Human Settlements. Pretoria: Department of Rural Development and Land Reform.

Local Economic Development (LED). (2015). Local Economic Development: A Framework for the implementation of the Sustainable Development Goals in the Post-2015 Development Agenda. Third World Forum of Local Economic Development (pp. 1-19). Torino: Local Economic Development (LED).

Locatelli, B., Brockhaus, M., Buck, A., Thompson, I. Forests and Adaptation to Climate Change: Challenges and Opportunities. Gerardo Mery, Pia Katila, Glenn Galloway, Ren’e I. Alfaro, Markku Kanninen, Max Lobovikov and Jari Varjo. Forests and Society - Responding to Global Drivers of Change, IUFRO, pp.21-42, 2010, IUFRO World Series Volume 25, 978-3901347-93-1. <cirad-00699347>

Maddison, D. (2007). The Perception of and Adaptation to Climate Change in Africa. Birmingham: The World Bank Development Research Group Policy Research Working Paper 4308.

Marrewijk, L. 2011. Climate Smart Agriculture in the Mutale Basin, South Africa. MSc Thesis. Vrije Universiteit (VU) Amsterdam

Marshall N., Marshall P., Tamelander J., Obura D., Malleret-King D. and Cinner J. (2010). A Framework for Social Adaptation to Climate Change: Sustaining Tropical Coastal Communitites and Industries. Gland, Switzerland: IUCN Climate Change and Coral Reefs Working Group.

McNamara, K. E. (2011). Exploring adaptive capacity to climate change: The development of a household survey. PACE-SD Occasional Paper No. 2011/1. Suva, Fiji Island: The University of the South Pacific.

Mendis S., S. Mills, and J. Yantz. (2003). Building community capacity to adapt to climate change in resource-based communities. Manitoba: Prince Albert Model Forest.

Moghal, Z. (2011). Assessing Climate Change Vulnerability and Adaptive Capacity of Small Island Tourism Destination: Why Non-Climatic Factors and Climate Change need an equal platform. Initiative on Climate Adaptation Research and Understanding through the Social Science (ICARUS) - Conference Proceedings

Motsholapheko, M. R., Kgathi, D.L., and Vanderpost, C. (2011). Rural livelihoods and household adaptation to extreme flooding in the Okavango Delta, Botswana. Physics and Chemistry of the Earth, 36(14-15), pp.984-995. 
Musyoki, A. (2012). The Emerging Policy for Green Economy and Social Development in Limpopo, South Africa. Geneva: United Nations Research Institute for Social Development.

Mruthyunjaya B. C., and S. Selvarajan. (2002). Vulnerability to Climate Induced Natural Disasters with Special Emphasis on Coping Strategies of the Rural Poor in Coastal Orissa, India. UNFCC COP8 Conference (pp. 1-16). New Delhi: United Nations Environment Programmes.

Nkomwa, E. C., Joshua,M.K., Ngongondo, C., Monjerezi, M., and Chipungu, F. (2014). Assessing indigenous knowledge systems and climate change adaptation strategies in agriculture: A case study of Chagaka Village, Chikhwawa, Southern Malawi. Physics and Chemistry of the Earth $67-69,164-172$.

Nzuma, J. M., Waithaka, M., Mulwa, R. M., Kyotalimye, M., and Nelson, G. (2010). Strategies for Adapting to Climate Change in Rural Sub-Saharan Africa. Nairobi: IFPRI Discussion Paper 01013.

Panda, A., Sharma, U., Ninan, K.N., and Patt, A. (2013). Adaptive capacity contributing to improved agricultural productivity at the household level: Empirical findings highlighting the importance of crop insurance. Global Environmental Change 23 , 782-790.

Patt, A. G., M. Tadross, P. Nussbaumer, K. Asante, M. Metzger, J. Rafael, A. Goujon, and G. Brundrit. 2010. Estimating least-developed countries' vulnerability to climate-related extreme events over the next 50 years. Proceedings of the National Academy of Sciences of the United States of America 107:1333-1337.

Paumgarten, F., and Shackleton, C.M. (2011). The role of non-timber forest products in household coping strategies in South Africa: the influence of household wealth and gender. Population Environment Volume 33, 108-131.

Perlis A. (2009). Food and Agriculture; Unasylva 231/232. An international journal of forestry and forest industries, Volume 60, 5-63.

Pramova,E., Locatelli, B., Djoudi, H., and Somorin, O.A. (2012). Forests and trees for social adaptation to climate variability and change. WIREs Clim Change, 3, 581-596.

Quinn, C. H., Ziervogel, G., Taylor, A., Takama, T., and Thomalla, F. (2011). Coping with Multiple Stresses in Rural South Africa. Ecology and Society 16(3): 2 , 1-20.

Robledo, C., Clot, N., Hammill, A., Riché, B. (2012). The role of forest ecosystems in communitybased coping strategies to climate hazards: Three examples from rural areas in Africa. Journal of Forest Policy and Economics issue 24 , 20-28.

Roncoli M C, Ingram K and Kirshen P .(2001). The costs and risks of coping with drought: livelihood impacts and farmers' responses in Burkina Faso Climate Research 19 119-132

Rosmarin J .(2013) Vhembe biospehere reserve. Retrieved August 1, 2014, from Environmental Affairs:

www.environment.gov.za/?q=content/projects programmes/manand thebiosphere reserves/list $\underline{\text { vhembe }}$

Sebastian Oberthür, Antonio G. M. LA Viña, Jennifer Morgan. (2015). Getting specific on the 2015 climate change agreement: suggestions for the legal text with an explanatory memorandum. The Agreement for Climate Transformation (ACT), Working Paper. Washington, DC 20002: World Resource Institute (WRI). 
Shackleton, S.E., Campbell, B., Lotz-Sisitka, H. \& Shackleton, C.M. 2008. Links between the local trade in natural products, livelihoods and poverty alleviation in a semi-arid region of South Africa. World Development, 36: 505-526.

Statistics South Africa. (2011). Census 2011. http://www.statssa.gov.za/?page id=3955

Striessnig, E., W. Lutz, and A. G. Patt. (2013). Effects of educational attainment on climate risk vulnerability. Ecology and Society 18(1): 16. http://dx.doi.org/10.5751/ES-05252-180116

Tembo, M. D. (2013). A dynamic assessment of adaptive capacity to climate change: A case study of water management in Makondo, Uganda. Maynooth: PhD Thesis; National University of Ireland.

Thomas, D.S.G., Twyman, C., Osbahr, H., and Hewitson, B. (2007). Adaptation to climate change and variability: farmer responses to intra-seasonal precipitation trends in South Africa. Climatic Change, 83, 301-322.

Turner, B.Kasperson, R. Matsone, P. McCarthy, J. Corellg, R. Christensene, L. Eckleyg, N. Kasperson, J. Luers, A. Martellog, M. Polsky, C.Pulsipher, A.\& Schiller, A. 2003. A framework for vulnerability analysis in sustainability science.PNAS 100 (14), 8074-8079.

Turpie J, and Visser M (2013) The impact of climate change on South Africa's rural areas. In F. a. Commission, Submission for the 2013/14 Division of Revenue (pp. 100-162). Cape Town: Financial and Fiscal Commission.

Twomlow, S., Mugabe, F., T., Mwale, M., Delve, R., Nanja, D., Carberry, P., and Howden, M. (2008). Building adaptive capacity to cope with increasing vulnerability due to climatic change in Africa - A new approach. Physics and Chemistry of the Earth 33 , 780-787.

Valdivia C., L. Gilles, C.Jetté, and R. Espejo,. (2005). Coping and adapting to climate variability: the role of assets, networks, knowledge and institutions. Washington, DC: NOAA - National Oceanic and Atmospheric Administration.

VBR (Vhembe Biosphere Reserve). 2012. Vhembe Biosphere Reserve, Ecosystem Services Analyses, October 2012

Viljoen, W. (2013). Addressing climate change issue in eastern and southern Africa: EAC, COMESA, SADC and the TFTA. Cape to Cairo: Exploring the Tripartite FTA agenda (pp. 1-35). Nairobi: Trade Law Centre and the Swedish Embassy.

Wall E., and K. Marzall. (2006). Adaptive Capacity for Climate Change in Canadian Rural Communities. Local Environment, Volume 11, Issue 4, , 373-397.

Wikipedia. (n.d.). Vhembe District Municipality. Retrieved June 27, 2015, from Wikipedia: The Free Encyclopedia: https://en.wikipedia.org/wiki/Vhembe_District_Municipality

Wilk, J., Andersson, L., and Warburton, M. (2013). Adaptation to climate change and other stressors among commercial and small-scale South African farmers. Reg Environ Change, 13, $273-$ 286.

Williams, M., and Kalamandeen, M. (2013). Assessing the Adaptive Capacity of Coastal Communities in Guyana to Climate Change. scientific reports, volume 2, issue 2, 1-6. 